\title{
Using Collaborative Technologies and Social Media to Engage Citizens and Governments during the COVID-19 Crisis. The Case of Spain
}

\author{
J. IGNACIO CRIADO, ARIANA GUEVARA-GÓMEZ, and JULIÁN VILLODRE, Universidad
}

Autónoma de Madrid, Department of Political Science and International Relations

During the COVID-19 crisis, governments around the world have been organizing activities to foster citizens' participation during the lockdown. In Germany and Estonia, for example, their governments launched civic hackathons during March 2020 to find new solutions to the challenges associated with the COVID-19 crisis. This article is intended to provide evidence about the utilization of collaborative and social platforms to foster co-production with citizens during the COVID-19 crisis in Spain. In the case of "Frena la Curva," (Flattening the Curve), a metalab fostered by the innovation lab of the regional Government of Aragon, the scalability of the platform has even facilitated spreading this collaborative initiative to different countries. Regarding the use of social media hashtags, including “\#EsteVirusLoParamosUnidos," Spanish authorities have encouraged citizen-networked co-production for communication and crisis coordination. These two cases illustrate how digital platforms have been used to offer a more agile response to COVID-19.

CCS Concepts: • Information systems $\rightarrow$ Internet communications tools;

Additional Key Words and Phrases: Public innovation, collaborative governance, digital platforms, Spain

ACM Reference format:

J. Ignacio Criado, Ariana Guevara-Gómez, and Julián Villodre. 2020. Using Collaborative Technologies and Social Media to Engage Citizens and Governments during the COVID-19 Crisis. The Case of Spain. Digit. Gov.: Res. Pract. 1, 4, Article 30 (September 2020), 7 pages.

https://doi.org/10.1145/3416089

\section{INTRODUCTION}

During the COVID-19 crisis, governments have been using information and communication technologies (ICTs) with different approaches and purposes. Most of them have developed apps, drones, and big data dashboards to assess the spread of the coronavirus or monitor the behavior of people during the confinement [Nanni et al. 2020; The Rockefeller Foundation 2020]. While there are reasons to claim that these initiatives have helped to contain the effects of the COVID-19 in different countries [Huang Sung and Sui 2020], there are also debates about the

This study was supported by the Research Grant RTI2018-095344-A-I00 (SmartGov_Local), Spanish Ministry of Science and Innovation. Authors' addresses: J. I. Criado, A. Guevara-Gómez, and J. Villodre, Universidad Autónoma de Madrid, Building of Law, Politics and Economics, 1st floor. C/ Marie Curie, 1, Ciudad Universitaria de Cantoblanco, 28049, Madrid, Spain; emails: ignacio.criado@uam.es, arguego@gmail.com, julian.villodrede@uam.es.

Permission to make digital or hard copies of all or part of this work for personal or classroom use is granted without fee provided that copies are not made or distributed for profit or commercial advantage and that copies bear this notice and the full citation on the first page. Copyrights for components of this work owned by others than ACM must be honored. Abstracting with credit is permitted. To copy otherwise, or republish, to post on servers or to redistribute to lists, requires prior specific permission and/or a fee. Request permissions from permissions@acm.org.

(c) 2020 Association for Computing Machinery.

2639-0175/2020/09-ART30 \$15.00

https://doi.org/10.1145/3416089

Digital Government: Research and Practice, Vol. 1, No. 4, Article 30. Publication date: September 2020. 
implications for citizens' privacy and individual rights [Ko 2020; Marr 2020; Wang 2020]. Despite these debates on personal data and surveillance are of paramount importance, there is another perspective for the implementation of ICTs during the crisis that still requires attention: Governments could use them to enhance the collaboration and co-production with citizens and find new solutions to emerging and complex societal challenges. This article is intended to provide evidence about the utilization of collaborative and social platforms to foster co-production with citizens during the COVID-19 crisis in Spain.

\section{COLLABORATIVE AND SOCIAL TECHNOLOGIES FOR CO-PRODUCTION IN GOVERNMENT}

In line with these ideas, there are examples of public innovation initiatives and the use of collaborative and social media technologies in the public sector to promote collaboration, dissemination of useful information, and cocreation during the health crisis. These trends have emerged in past years in the public sector as a means to create public value through emerging technologies, according to the notion of smart governance [Criado and Gil-García 2019], and the COVID-19 outbreak has been an opportunity to experiment with this perspective. Through these initiatives, governments aim to foster inclusion, participation, and democratic values, but also enhance the co-creation of cutting-edge solutions [McGann et al. 2018] to share responsibilities in a scenario of uncertainties and complexity.

Regarding public innovation initiatives based on collaborative platforms, governments around the world have been organizing activities to foster citizens' participation during the confinement. In Germany and Estonia, for example, their governments launched civic hackathons during March 2020 to find new solutions to the challenges associated with the COVID-19 crisis [DW 2020; Ministry of Foreign Affairs of the Republic of Estonia 2020]. In Spain there are also examples: one of them is the hackathon "Vence al Virus" (Fight the Virus), promoted by the Autonomous Community of Madrid; and "Frena la Curva" (Flattening the Curve), a metalab fostered by the innovation lab of the regional Government of Aragon. All these initiatives have in common their collaborative nature: Public and private organizations have partnered to implement the innovation strategies and include the citizens in the process of solutions co-creation. Thus, they all aim to foster what is called the Public-Private-People Partnership, or 4P [Shin 2019], and, more comprehensively, the collaborative governance approach [Sørensen and Torfing, forthcoming].

Also, this health critical situation has tested the response capabilities of governments worldwide, including how to deliver public information and engage citizens via social media. In emergency situations, social media could assist governments and public administration to streamline their communications, prevention, and coordination of response activities [Wukich 2016]. This is so as these platforms enable what scholars have named as citizen networked co-production [Chatfield and Reddick 2018; Chatfield et al. 2013] (i.e., situations with governments' communication and coordination responses overwhelmed by an emergency crisis); hence, social media might help authorities to spread their messages due to the collaborative action of citizens sharing and even posting additional information. Since the beginning of the crisis, the Spanish Government, as well as many others, used social media (mostly Twitter) to provide information, encouraging citizens to socialize critical messages and collaboration using the hashtag \#EsteVirusLoParamosUnidos (\#UnitedWeStopThisVirus). However, we need to deepen our understanding of what types of actors are interacting and how they are behaving within concrete contexts generated inside these networks, and the collaboration with governments and co-production dynamics [Wukich et al. 2019; Reuter and Kaufhold 2018]. Regarding public managers, understanding these processes could be essential to promote proactive responses among citizens, as well as to help authorities targeting appropriate audiences.

\section{COLLABORATIVE PUBLIC INNOVATION IN SPAIN. THE CASE OF FRENA LA CURVA}

In Spain, there are experiences of public innovation initiatives during the COVID-19 crisis that could be labeled as "islands for experimentation" [Tõnurist et al. 2017]. One of them is "Frena la Curva" (Flattening the Curve),

Digital Government: Research and Practice, Vol. 1, No. 4, Article 30. Publication date: September 2020. 
a collaborative digital platform, or metalab, which aims to join "volunteers, entrepreneurs, activists, social organizations, makers, and public innovation labs to channel and organize the social energy and civic resilience during the COVID-19 pandemic (coronavirus), providing a solution from the civil society, complementary to the government's and public services" [Frena la Curva 2020]. The initiative began on March 12th, 2020, as an idea of the Laboratorio de Aragón (Gobierno) Abierto, an innovation and governance lab created by the Government of Aragon (a regional government in Spain). During the following days, private companies and civic organizations joined the project, which we could consider as a citizen-to-citizen initiative [Reuter and Kaufhold 2018]. At this moment (June, 30th), 68 entities are collaborating with the initiative in Spain, and 22 countries have replicated the platform locally, mostly in Latin American countries.

The main feature of "Frena la Curva" is a collaborative map to connect people and organizations providing help during the confinement with citizens who need it. In mid-June, there were more than 7,000 offerings and 160 demands for support. Besides the participants from private organizations and individuals, the map also counts public servants "on-call," who act as volunteers to answer questions about administrative procedures, refer citizens to the official information channels, and provide guidance in the requests of public services. In this case, it is difficult to know how many officials are registered in the map, because the data of this category are mixed with other types of requests and offerings. Data from this case exhibit the following as the most usual (a) available services (Red Cross (744), food (613), and local businesses (494)), (b) offerings (food $(3,092)$, super-neighbor $(3,032)$, care/attention $(1,749)$ ), (c) own demands (food (57), makers/protective visors/3D masks/respirators... (49), hygiene (48)), (d) demands with intermediation (hygiene (99), health (98), makers/protective visors/3D masks/respirators... (66)).

"Frena la Curva" also develops the initiative "Desafios Comunes"(Common Challenges), which uses the methods of hackathons to collect ideas from individuals and civil society organizations. In April, the organizers received 140 proposals and selected 10, which were presented during the Frena la Curva festival, on May 2nd, 2020. At the same time, "Frena la Curva" established the Distributed Citizen Lab, which receives ideas from the general public through an online forum, available on the website. In this case, there are 13 proposals, with a total of 200 participants, which worked intensively for five days (between March 19th to 23rd) to make progress on their ideas. The site also includes a button to channel donations in the region of Aragon. Considering that this initiative includes other i-labs within it, a hackathon-inspired event, a digital and collaborative map, and sections to direct donations and other individual collaborations, it is possible to categorize it as a metalab, a broad environment of innovation, experimentation, and collaboration. Here, we pinpoint two cases: Ventanas que Unen (Connecting Windows) (https://www.ventanasqueunen.org), a bank of tablets, with Internet cards donated by the IT company Digimobil, to connect people living in elderly residences with their relatives (managed by volunteers, Aragon Institute for Social Services, and i-Lab of the Aragon Government); the other, Libros que Unen (Connecting Books) (https://librosqueunen.org), is an initiative to edit and deliver almost $12 \mathrm{~K}$ public domain books for primary school students (6 to 12 years old) with low level of connectivity, developing a network of volunteers to follow-up learning processes.

Broadly, this collaborative project aims to unite the efforts of public and private institutions, as well as citizens and civil society organizations, to create new solutions to complex societal issues. At the same time, this project shares some of the challenges of collaborative governance processes. Following the ideas explained by Sørensen and Torfing (forthcoming), there are doubts about the ability of this project to guarantee the implementation, evaluation, and accountability processes. Regarding the implementation process, "Frena la Curva" metalab was endorsed with a collaborative approach. It would be interesting to better understand the nature of the collaboration and the specific contributions of each actor, but despite this fact, this initiative indeed passed from ideation to reality. Although this project received ideas from citizens and civic organizations, it is not clear how they will be implemented and the level of public involvement in this process. In fact, in the case of "Frena la Curva," the commitment, after the presentation of proposals at the Frena la Curva festival, was to follow up on the support 


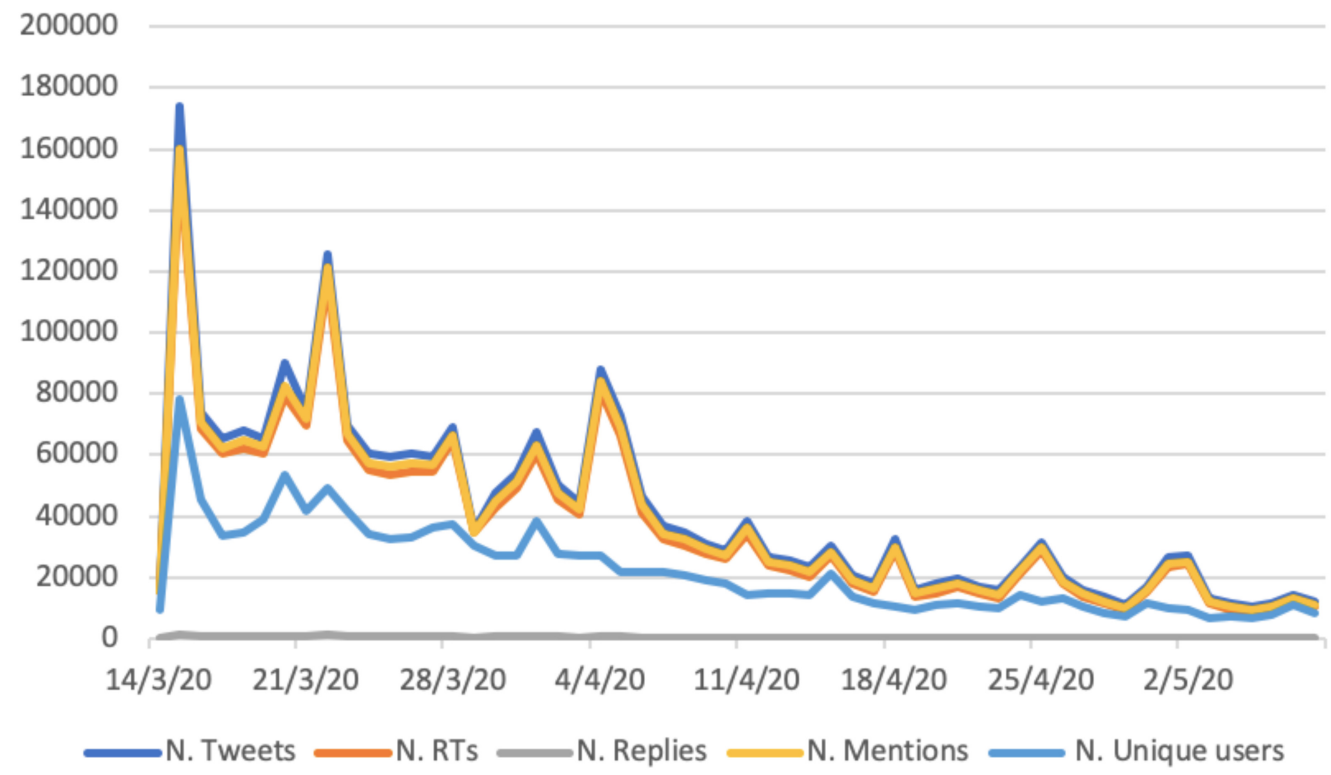

Fig. 1. \#EsteVirusLoParamosUnidos activity from March 14th to May $8^{\text {th }}, 2020$.

to facilitate the development of ideas, but there is not a promise from the public actors involved to implement the adopted solutions.

\section{CITIZEN-NETWORKED CO-PRODUCTION OF CRISIS COMMUNICATION USING SOCIAL MEDIA IN SPAIN. THE CASE OF \#ESTEVIRUSLOPARAMOSUNIDOS}

The Spanish government launched the hashtag \#EsteVirusLoParamosUnidos (\#UnitedWeStopThisVirus) the day of State of Alarm announcement (March 14th). Since then, this hashtag has been continuously displayed during official press conference and during Prime Minister public talks, as well as in appearances by other political leaders of the Spanish cabinet. Originally, it was designed as an institutional campaign in social media to raise awareness of the COVID-19 crisis and, at the same time, to engage with citizens during the hardest moments of the lockdown. Also, the campaign included recommendations from the Ministry of Health, as well as messages appealing to the civic common sense of the population to curb the contagion curve and keep mobility to the minimum. For this purpose, authorities sought to obtain citizens' help to achieve high levels of dissemination and searched for citizen-networked co-production [Chatfield and Reddick 2018]. Therefore, \#EsteVirusLoParamosUnidos (\#UnitedWeStopThisVirus) encompasses information and actions flowing from central government and public administrations to citizens (authority to citizens approach) [Reuter and Kaufhold 2018], broadly supported by citizens' retweets. Figure 1 displays data with the activity generated using this hashtag, showing its network potential in Spain during one of the strictest lockdowns in the world.

Here, we extracted more than $2 \mathrm{M}$ tweets in total for the analyzed timeframe. As Figure 1 shows, the periods of greatest activity, both in mentions and in published content and dissemination, correspond with the declaration of the State of Alarm and its implementation on the two following days (March 14th, 15th, and 16th), collecting more than $250 \mathrm{~K}$ tweets for this short period of time). In sum, this hashtag brought together a total amount of $1.2 \mathrm{M}$ unique users and left more than $2 \mathrm{M}$ retweets (RTs). These data, especially when referring to retweets, shows how citizens became involved in the constant and massive dissemination of tweets issued by Spanish authorities.

In general, actors with the most shared content include profiles of public agencies and authorities linked to the government and the public management of the crisis. Table 1 shows the most prominent actors by message

Digital Government: Research and Practice, Vol. 1, No. 4, Article 30. Publication date: September 2020. 
Table 1. Profiles with Most Shared Content (Top 10) in Spain for \#EsteVirusLoParamosUnidos

\begin{tabular}{|llcc|}
\hline Name of the organization/person & Twitter profile & $\begin{array}{c}\text { Retweets } \\
\text { (received) }\end{array}$ & $\begin{array}{c}\text { Retweets } \\
\text { (sent) }\end{array}$ \\
\hline Public Health Authority & @saludpublicaes & 146,390 & 115 \\
National Police & @policia & 142,485 & 5 \\
Health Ministry & @sanidadgob & 125,376 & 237 \\
Spanish Socialist and Workers Party & @psoe & 107,611 & 144 \\
Spanish Government & @desdelamoncloa & 101,167 & 141 \\
Pedro Sánchez (Prime Minister) & @sanchezcastejon & 84,436 & 195 \\
Civil Guard (Police corp) & @guardiacivil & 79,115 & 73 \\
Ministry of Defense & @defensagob & 31,751 & 45 \\
Yolanda Díaz (Work and Social Economy Minister) & @yolanda_diaz_- & 30,350 & 25 \\
Professional Football League (LaLiga) & @laliga & 27,373 & 57 \\
\hline
\end{tabular}

dissemination (received retweets), that is, by the scope that messages had regarding to the notion of propagation. The account of Public Health (@saludpublicaes), National Police (@policia), and the Ministry of Health (@sanidadgob) are among those that have managed to spread the most content. The strategy of these accounts has been engaging citizens to publish information with guidance and information about the virus, including issues as hygiene measures, protocols in case of experience virus symptoms, daily data updates, video with press conferences of public officials, and even advice to cope with quarantine and to avoid spreading of fake news in social media. Regarding retweets sent by authorities, the number of messages propagated by accounts such as the Ministry of Health (237 messages from other accounts) or Public Health (115) was considerably high. Despite public agencies being often reluctant to re-broadcast from other sources, in this case the numbers seem to indicate an interest in increasing the reach of messages from other sources (mostly official profiles). Therefore, this case is an initiative aimed at communicating relevant information about the crisis. Authorities posting critical information optimized the audience of their messages, thanks to the action of thousands of citizens who collaborated by retweeting the information they considered the most relevant from these sources. Accounts sending official COVID-19 related information about the virus, including the Ministry of Health or the Spanish National Police, gained more than $120 \mathrm{~K}$ retweets to their messages. Future research on this case should determine the influence that this diffusion has entailed on citizens' behaviors and networked citizen co-production.

\section{DEBATE}

We have identified two real cases using collaborative technologies and social media to engage citizens and governments for co-production practices during the COVID-19 crisis in Spain. Apart from the privacy and surveillance debates about the track and tracing apps, the most pervasive utilization of technologies during this health crisis in different countries has been oriented to foster the collaboration of citizens with public authorities, mostly during the hardest moments of the lockdown. In general, this has provided an example of future potential uses of technologies with innovative purposes, at the same time, making citizens more active in the collaboration processes. In the case of "Frena la Curva," the scalability of the platform has even facilitated spreading the collaboration to different countries. Regarding the use of social media hashtags, including "\#EsteVirusLoParamosUnidos," the Spanish authorities have pursued citizen-networked co-production and exchange of crisis communication since the beginning of the lockdown. All in all, these two cases have been documented and might enlighten future practices of collaboration by digital means.

Despite the objectives being clear and the intentions in line with the collaborative approach to the public sector management, using co-production digital platforms and social media technologies, some aspects also need 
to be further discussed. In general terms, it is not clear how these technological initiatives could help to promote democratic values [García Guitián 2016] and the creation of public value [Yuan and Gascó-Hernández 2019]. In the case of public innovation projects ("Frena la Curva"), there are some practical issues regarding the implementation and accountability of the process. Besides the questions about the real inclusiveness of all actors in the participation initiatives, it has been also stated that there are challenges in the collaborative governance processes, including the different stages of implementation, evaluation, and accountability [Sørensen and Torfing, forthcoming]. In the case of social media technologies during the COVID-19 crisis (i.e., hashtag \#EsteVirusLoParamosUnidos) they have given examples of citizens' engagement and networked co-production practices promoted by public authorities (mostly on Twitter). Here again, the diversity of actors and the accountability concerns raise questions on the potential of these tools to foster collaborative governance practices or even civic engagement [Feeney and Porumbescu 2020, forthcoming].

Comparatively, both "Frena la Curva" and "\#EsteVirusLoParamosUnidos" shared collaborative and networking perspectives, whereas they also exhibit some differences. In the first case, it was intended to promote collaboration with citizens during the hardest moments of the lockdown by developing a digital platform to place offerings and demands, and then evolving into a space of co-production with final products based on its scalability and reaching high social impact. However, \#EsteVirusLoParamosUnidos could be considered as a genuine social media authority-to-citizen initiative, specifically developed on social media platforms (Twitter) and mostly used to deliver time-critical information about the health crisis. Spanish authorities relied on citizens' willingness to propagate official information, which was essential to reach high levels of diffusion. Hence, crisis communication around this hashtag was co-produced with the citizenship. Future studies using available data (or personal interviews) will help to provide more answers (i.e., about motivations, enablers, and inhibitors for collaborative governance) in the upcoming stages of the crisis for the sake of collaborative governance practices in digital environments.

\section{REFERENCES}

Akemi Takeoka Chatfield and Christopher Reddick. 2018. All hands on deck to tweet \#sandy: Networked governance of citizen coproduction in turbulent times. Gov. Inf. Quart. 35, 2 (2018), 259-272. DOI: https://doi.org/10.1016/j.giq.2017.09.004

Akemi Takeoka Chatfield, Hans Jochen Scholl, and Uuf Brajawidagda. 2013. Tsunami early warnings via Twitter in government: Net-savvy citizens' co-production of time-critical public information services. Gov. Inf. Quart. 30, 4 (2013), 377-386. DOI : https://doi.org/10.1016/j. giq.2013.05.021

J. Ignacio Criado and J. Ramón Gil-García. 2019. Creating public value through smart technologies and strategies: From digital services to artificial intelligence and beyond. Int. f. Pub. Sect. Manag. 32, 5 (2018), 438-50. DOI : https://doi.org/10.1108/IJPSM-07-2019-0178

Lisa Hänel. 2020. German government hosts coronavirus pandemic hackathon. Retrieved from https://www.dw.com/en/germangovernment-hosts-coronavirus-pandemic-hackathon/a-53080512.

Mary K. Feeney and Gregory Porumbescu. 2020. The limits of social media for public administration research \& practice. Pub. Admin. Rev. (16 July 2020). DOI : https://doi.org/10.1111/puar.13276

Frena la Curva. 2020. Frenalacurva-Juntos somos más fuertes. Retrieved from https://frenalacurva.net/.

Elena García Guitián. 2016. Democracia digital. Discursos sobre participación ciudadana y TIC. Rev. Estud. Polít. 173 (July-Sept. 2016), 169193. DOI : https://doi.org/10.18042/cepc/rep.173.05

Yasheng Huang, Meicen Sung, and Yuze Sui. 2020. How digital contact tracing slowed Covid-19 in East Asia. Retrived from https://hbr.org/ 2020/04/how-digital-contact-tracing-slowed-covid-19-in-east-asia.

June Ko. 2020. How China used technology to combat COVID-19-and tighten its grip on citizens. Retrieved from https://www.amnesty.org/ en/latest/news/2020/04/how-china-used-technology-to-combat-covid-19-and-tighten-its-grip-on-citizens/.

Bernard Marr. 2020. COVID-19 Is changing our world-and our attitude to technology and privacy-why could that be dangerous? Retrieved from https://www.forbes.com/sites/bernardmarr/2020/03/23/covid-19-is-changing-our-world-as-well-as-our-attitudeto-technology-and-privacy-why-could-that-be-a-problem/\#61621c126dc1.

Ministry of Foreign Affairs of the Republic of Estonia. 2020. Hacking the crisis. Retrieved from https://vm.ee/en/hacking-crisis.

Michael McGann, Emma Blomkamp, and Jenny M. Lewis. 2018. The rise of public sector innovation labs: Experiments in design thinking for policy. Policy Sci. 51 (2018), 249-67. DOI : https://doi.org/10.1007/s11077-018-9315-7

Mirco Nanni, Gennady Andrienko, Chiara Boldrini, Francesco Bonchi, Ciro Cattuto, Francesca Chiaromonte, and Virginia Dignum. 2020. Give more data, awareness and control to individual citizens, and they will help COVID-19 containment. Arxiv Preprint Arxiv:2004.05222.

Digital Government: Research and Practice, Vol. 1, No. 4, Article 30. Publication date: September 2020. 
Christian Reuter and Marc André Kaufhold. 2018. Fifteen years of social media in emergencies: A retrospective review and future directions for crisis informatics. F. Conting. Crisis Manag. 26, 1 (2017), 41-57. DOI : https://doi.org/10.1111/1468-5973.12196

Donghee Shin. 2019. A living lab as socio-technical ecosystem: Evaluating the Korean living lab of internet of things. Gov. Inf. Quart. 36, 2 (2019), 264-275. DOI : https://doi.org/10.1016/j.giq.2018.08.001

Eva Sørensen and Jacob Torfing. Forthcoming. Radical and disruptive answers to downstream problems in collaborative governance?

The Rockefeller Foundation. 2020. Integrating digital technology and public health to fight Covid-19: Linking China's experiences to the world. Retrieved from https://www.rockefellerfoundation.org/case-study/covid-19-linking-chinas-experiences-to-the-world/.

Piret Tõnurist, Rainer Kattel, and Veiko Lember. 2017. Innovation labs in the public sector: What they are and what they do? Pub. Manag. Rev. 19, 2 (2017), 1455-1479. DOI : https://doi.org/10.1080/14719037.2017.1287939

Maya Wang. 2020. China: Fighting COVID-19 With automated tyranny. Retrieved from https://www.hrw.org/news/2020/04/01/chinafighting-covid-19-automated-tyranny.

Clayton Wukich, Qian Hu, and Michael D. Siciliano. 2019. Cross-sector emergency information networks on social media: Online bridging and bonding communication patterns. Amer. Rev. Pub. Admin. 49, 7 (2019), 825-839. DOI : https://doi.org/10.1177/0275074019861701

Clayton Wukich. 2016. Government social media messages across disaster phases. F. Conting. Crisis Manag. 24, 4 (2016), 230-243. DOI: https://doi.org/10.1111/1468-5973.12119

Qianli Yuan and Mila Gascó-Hernández. 2019. Open innovation in the public sector: Creating public value through civic hackathons. Pub. Manag. Rev. (10 Dec. 2019). DOI : https://doi.org/10.1080/14719037.2019.1695884

Received July 2020; revised July 2020; accepted July 2020

Digital Government: Research and Practice, Vol. 1, No. 4, Article 30. Publication date: September 2020. 